\title{
RECORDS OF THE MIDDLE - AND LATE HOLOCENE PALAEOENVIRONMENTAL CHANGES IN THE PCIM-SUCHA LANDSLIDE PEAT BOGS (BESKID MAKOWSKI MTS., POLISH OUTER CARPATHIANS)
}

\author{
WLODZIMIERZ MARGIELEWSKI ${ }^{1}$, ADAM MICHCZYŃSKI ${ }^{2}$, and ANDRZEJ OBIDOWICZ ${ }^{3}$ \\ ${ }^{1}$ Institute of Nature Conservation, Polish Academy of Sciences, A. Mickiewicza 33, 31-120 Kraków, Poland \\ ${ }^{2}$ GADAM Centre of Excellence, Institute of Physics, Silesian University of Technology, Krzywoustego 2, 44-100 Gliwice, Poland. \\ ${ }^{3}$ Institute of Botany, Polish Academy of Sciences, Lubicz 46, 31-120 Kraków, Poland
}

\begin{abstract}
The paper presents analysis of depositional sequences of two peat bogs situated in the depressions developed within the landslide landforms Pcim Sucha in the Beskid Makowski Mts. (Outer Carpathians). The older peat bog, with depositional sequence $3.75 \mathrm{~m}$ long, started to form at the decline of the Boreal Phase ca 7570-7330 cal BC. Palynological and lithological analyses as well as numerous (18) radiocarbon datings of different horizons in the sediment enabled reconstruction of palaeoenvironmental changes of the Middle and Late Holocene. Increase in climate humidity at the beginning of the Atlantic, Subboreal and Subatlantic Phases were observed as deliveries of minerogenic material to the peat bog basin and formation of illuvial and mineral layers within peat. The particularly intensive delivery of allochtonous material to the peat bog took place at the beginning of the Subatlantic Phase and was the result of both significant humid climate and increased human impact (colonization of the Przeworsk Culture) in the landslide area. Rejuvenation of the landslide zone and formation of the second landslide were connected with this period and processes. Deposits of peat bog situated within this younger landslide, which are ca $1.3 \mathrm{~m}$ thick, are significantly contaminated with mineral material.
\end{abstract}

Keywords: landslide peat bogs, palaeoenvironmental changes, Middle - and Late Holocene, Human impact, Polish Flysch Carpathians

\section{INTRODUCTION}

Depressions lying within landslides are often filled with water, if their bottoms are sealed with clay sediments. Such water basins are overgrown by plants and are gradually being filled with sediments, and subsequently transformed into peat bogs, usually of fen type (minerogenic mire). In regard to the specific hydrogeological conditions as well as character of sediments, they represent a specific type of peat bogs, called landslide peat bogs (Margielewski, 2006a; Obidowicz and Margielewski, 2008). The specific character of the deposition in these peat bogs is connected with frequent supplies of allochthonous, mineral material to the basins. This process is driven by the slopewash (sheet and linear erosion of slopes) induced in the area of head scarp

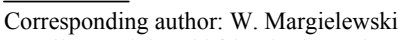

e-mail: margielewski@iop.krakow.pl

ISSN 1897-1695 (online), 1733-8387 (print) (C) 2010 GADAM Centre, Institute of Physics, Silesian University of Technology.

All rights reserved. and colluvia due to intensive or prolonged rains (Margielewski, 2001 and 2006a). Intensification of these processes is favored by human impact connected with intensive cultivation of the flat landslide areas, which began even in prehistoric time (see Starkel, 1988; Margielewski, 2000 and 2006a; Zolitschka et al., 2003). Sediments of the landslide peat bog are very sensitive indicators of palaeoenvironmental changes. Their detailed analysis enables reconstruction of not only palaeoclimatic changes of the Late Glacial and the Holocene but also of phases of human colonization related to the spread of prehistoric cultures in the area of the Carpathians, as well (Margielewski et al., 2003 and 2010; Margielewski, 2006a).

This type of landslide peat bogs were formed within the landslide area in the vicinity of Pcim-Sucha village, in the Beskid Makowski Mts., on the right bank of Mała Sucha stream (Raba river catchment area) (Fig. 1).

The peat bogs fill the depression situated at the foot of landslide head scarp. 


\section{GEOLOGICAL SETTING}

The landslide of Pcim-Sucha is situated in the eastern part of the Beskid Makowski (Beskid Średni) Mts., in geological terms within the zone of the Siary Subunit, Magura Unit (Fig. 1) (Burtan, 1977 and 1978; Wójcik and Raczkowski, 1994). It developed within Sub-Magura Beds of glauconitic facies, forming the Lubomir Syncline. The Sub-Magura beds consist of shales interbedded with thick-bedded glauconitic sandstones. Occasionally inserts of thin-bedded sandstones occur in this series (Burtan, 1978). Densely jointed, thick-bedded sandstones as well as layers of shells crop out within the landslide.

The landslide (strictly the landslide zone), within which the depression filled with fen peat bog lies, developed on the south slope of a small hill, on the right slope of Mała Sucha stream valley (the tributary of Suszanka creek within the catchment area of Raba river).

\section{LANDSLIDE DESCRIPTION}

The landslide formed within thick-bedded sandstones interbedded with thin-bedded sandstones and shales (in outcrops the thickness of shale inserts ranges 1.5-2.0 m). The landslide zone consists of two forms of different age, closed with characteristic elongated rampart of colluvial swell (Fig. 2a, c) (Margielewski, 2006a). Specific head scarps - relatively gently dipping, with indistinct upper edges characterize both forms, although they cross sufficiently clear, so as to distinguish succession of the landslides. The age of both landslides, determined by radiocarbon dating, confirms the geomorphological observations of succession - the older landslide (Pcim Sucha 1) is situated in the eastern part of the zone, while the younger landslide (Pcim Sucha 2) represents the western part of the zone (Margielewski, 2006a) (Fig. 2a, c).

Within the older landslide (in the eastern segment of the zone) a characteristic depression is situated at the head scarp foot (Fig. 2a, b). The depression of irregular triangle shape is ca $70 \mathrm{~m}$ long and ca $30 \mathrm{~m}$ wide, whereas its maximum depth reaches $3.75 \mathrm{~m}$. It is delimited by the landslide head scarp from the north and colluvial ramparts from south and east (Fig. 2b). Currently, it is filled with organic-mineral sediments of fen peat. The head scarp covered by weathered material, dips relatively gently. The upper edge of the head scarp is relatively apparent in its eastern part. In the upper segments of slope the traces of landslide scarps representing older generations of mass movements are visible (Fig. 2a). The through of SW-NE direction, which reaches the sub-summit part of slope is distinct element of mass movement of an older generation. Although the stream, forming locally even terrace levels, currently shapes this trough (particularly in the lower part), its genesis is evidently connected with the mass movements.

The colluvial rampart occurring within the analyzed landslide and delimiting the sub-scarp depression from the south is elongated east-west and stands ca 2-2.5 m above the peat bog surface. It slopes to the south with a scarp ca $7 \mathrm{~m}$ high, with numerous small rock formations representing rotated blocks of thick-bedded sandstone. The next elongated colluvial rampart runs from the main
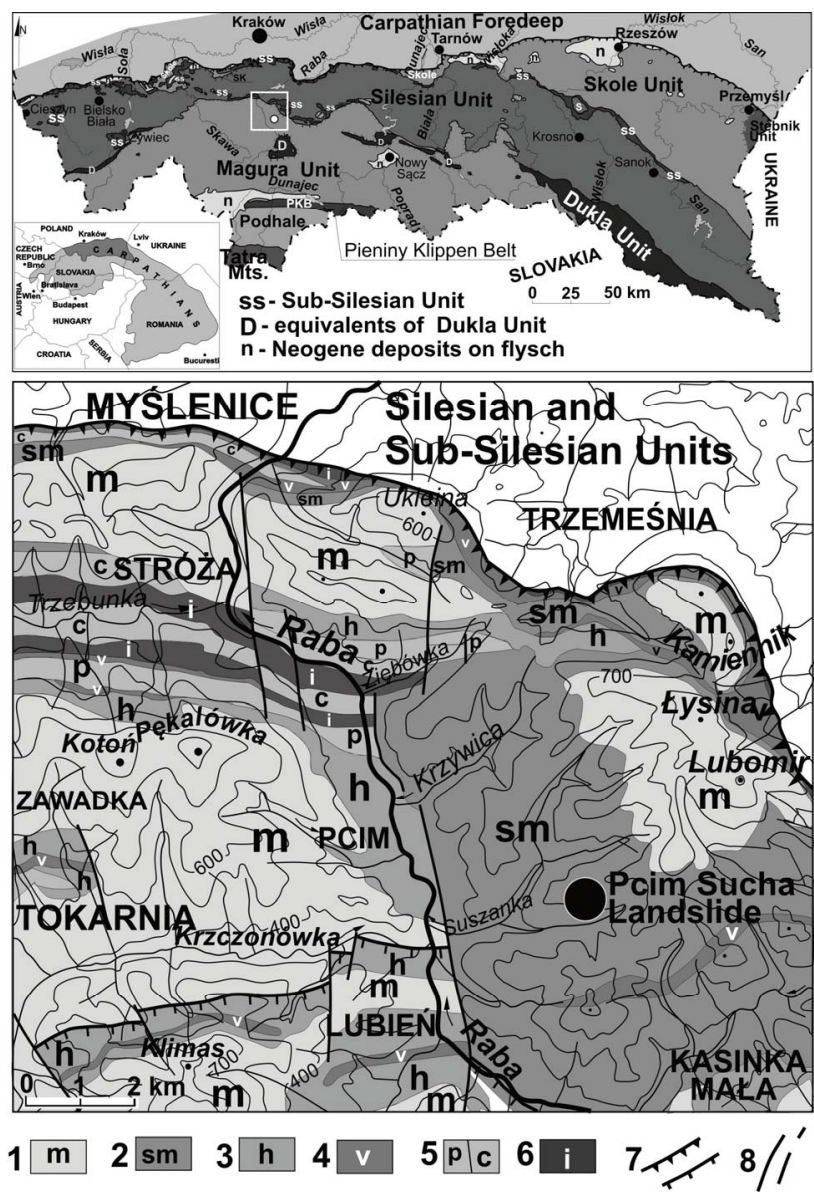

Fig. 1. Situation of the Pcim-Sucha landslide in the Polish Carpathians, on the background of geological map. Geology of the Carpathians after: Żytko et al., 1989, geology of the landslide area - compilation after: Burtan, 1977; Wójcik and Rączkowski, 1994. Explanation of symbols (Magura Unit): 1 - Magura beds; 2 - Sub-Magura beds; 3 Hieroglyphic beds; 4 - variegated shales; 5 - thick bedded sandstones with shales ( $p$ - Pasierbiec Sandstones; c - Ciężkowice Sandstones), 6 - Inoceramian beds; 7 - thrusts; 8 - faults.

rampart to the southwest, towards the valley of Mała Sucha stream (Fig. 2a, b, c). In the lower part it is cut by a scarp of the younger landslide, transforming colluvium of the older one. Colluvial flats and swells in the lowermost near-valley parts of the landslide zone are currently occupied by houses and farms.

The colluvial rampart bordering the landslide from the east is relatively flat and separates the landslide from the V-shaped stream valley. This valley - right tributary of Mała Sucha stream (using the landslide trough, described above, in its upper parts, of the NE-SW course, roughly turns in the vicinity of the colluvial rampart into NNWSSE direction. Downstream, after cutting the rampart closing the sub-scarp depression, it turns back to the former course (Fig. 2a, c). It is symptomatic that, in the zone of the colluvial rampart bordering the peat bog from the east, significant increase of valley depth (from $2 \mathrm{~m}$ to $8 \mathrm{~m}$ ) is observed. Deepening of the ravine is connected with several waterfalls $2.5-3.0 \mathrm{~m}$ high, formed of thickbedded sandstones (Fig. 2a). The next slope break in the longitudinal profile of the valley, situated near the colluvial rampart delimiting the depression from the south, is lithologically controlled (thick shale layer crops out 


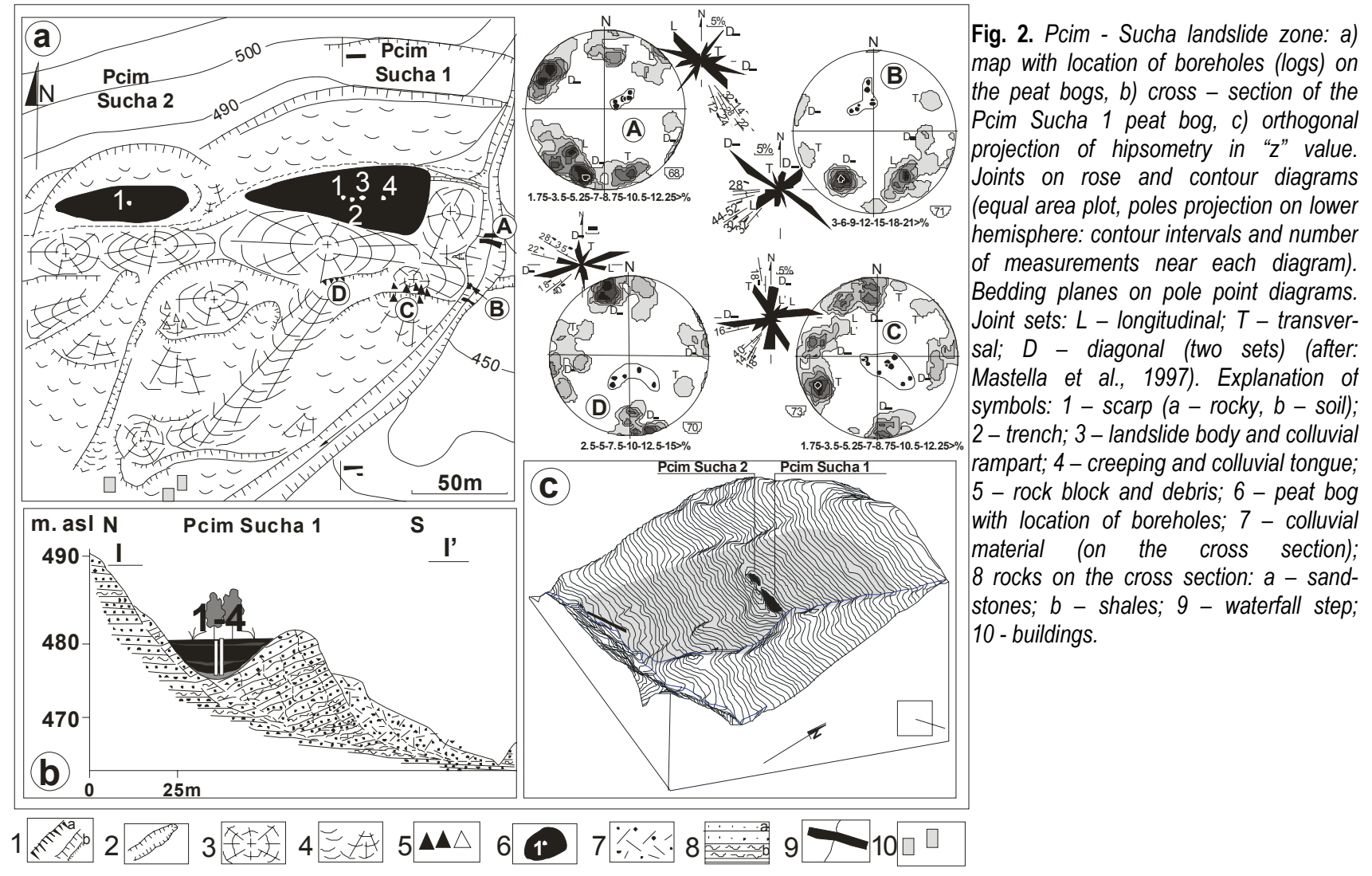

downstream). Valley depth increases here extending 10 $\mathrm{m}$. Within the lower segments of the landslide average valley depth diminishes and ranges 4-8 $\mathrm{m}$.

Analysis of orientation of thick-bedded sandstones, outcropped in the vicinity of the landslide and within its body indicates, that the rock massif was moved subsequently to the in situ strata (dipping towards SW at an angle of $14-30^{\circ}-$ measurements in the waterfall step: Fig. 2 - diagram: A). Although in the lower parts of the valley, the strata dip concordant to the mass movement (consequent) is also observed. Generally, orientation of structural surfaces (joints, bedding planes) measured within the landslide body indicates, that the displaced material underwent reverse rotation (the strata dip angle reaches increases from $14-30^{\circ}$ to $22-40^{\circ}$ ) as well as rotation around the vertical axis (see Fig. 2 - relation between diagrams: A and C-D as well as diagrams: A and B). Consequently, the landslide represents rotational type (Dikau et al., 1996) generally developed subsequently to the strata orientation (see: Margielewski, 2006b). Numerous rock surfaces covered with tectonic mirrors prove the dislocation zone, favoring gravitational movements.

Formation of the landslide was connected with erosional undercutting of the slope foot by Mała Sucha stream (part of the colluvial material, especially of the younger landslide, strictly narrows the valley). The vertical and horizontal erosion of the tributary of Mała Sucha stream could have played significant role in the initiation of the secondary mass movements within the landslide body (colluvium). Currently visible rough change of the stream course next to the main part of the colluvial rampart (where the "valley gap" is formed) indicates that this turning was definitely forced by landslide (Fig. 2a, c).
The mass movements, which rejuvenated the western parts of the landslide zone, formed an oval depression sized $50 \times 20 \mathrm{~m}$ and situated at the head scarp foot. Currently it is filled with organic-mineral sediments of maximum thickness $1.3 \mathrm{~m}$. At the top part of the depositional sequence mineral cover of thickness $0.8 \mathrm{~m}$ occurs (Margielewski, 2006a). Generally, the marsh surface of this depression is situated $4 \mathrm{~m}$ above the surface of the main (eastern) peat bog, while the elongated colluvial rampart also dams water outlet (Fig. 2a).

\section{MATERIAL AND METHODS}

The main peat bog (Pcim-Sucha 1) was investigated with numerous boreholes. Four logs taken at different parts of the peat bog were analyzed (Figs. 2a, 3). The boreholes were drilled with the peat sampler INSTORF (Russian peat sampler), $6 \mathrm{~cm}$ and $8 \mathrm{~cm}$ in diameter. Loss on ignition analyses at a temperature $550^{\circ} \mathrm{C}$ (Heiri et al., 2001 ) were made for each $2,5 \mathrm{~cm}$ long section of the logs. Loss on ignition curves were constructed for every log on the basis of these analyses (Figs. 3, 4).

Organic sediments were identified by Dr. K. Lipka from the Agriculture University in Cracow, based on peat classification according to Tołpa et al. (1971). Peat analyses were accompanied with description of plant macrofossils, which were determined also by Dr. K. Lipka.

Minerogenic sediments occurring within the peat bog were identified on the basis of Bouyoucos-Casagrande aerometric analyses modified by Prószyński (MycielskaDowgiałło and Rutkowski, 1995). Identification of these sediments was performed according to the Pettijohn clas- 
sification (Pettijohn, 1975; Battaglia et al., 2002) using Wentworth's scale of grain size (Wentworth, 1922). The granulometric indexes: mean grain size $(\mathrm{Mz})$ and standard deviation $\left(\sigma_{1}\right)$, were calculated for analyzed mineral sediments (after Folk and Ward, 1957).

Conventional radiocarbon dates reported in the article (Table 1) were carried out using various materials in the Radiocarbon Laboratory of the Ukrainian Academy of Sciences in Kiev (laboratory code - Ki), in the Radiocarbon Laboratory of the National Academy of Sciences of Belarus in Mińsk (laboratory code - IGSB) and in the Radiocarbon Laboratory of the Silesian University of Technology in Gliwice, Poland (laboratory code - Gd). Material for AMS datings (laboratory code - GdA) was collected from $\log 2$ at 19 different depths, each one centimeter thick. In 8 of these samples we found different type of macrofossils (mainly seeds of Carex sp.), which were then dated. The macrofossils were prepared using standard acid-alkali-acid method and processed to graph- ite targets (Czernik and Goslar, 2001) in the Radiocarbon Laboratory of the Silesian University of Technology in Gliwice. Then they were measured in the Poznań Radiocarbon Laboratory (Goslar et al., 2004). Calibration of the radiocarbon dates (expressed as cal yr BC/AD time intervals with probability $95 \%$ ) was done using the calibration data set IntCal04 (Reimer et al., 2004) and OxCal (version 3.10) calibration program (Bronk Ramsey, 1995; 2001). Generally, within the described peat bog 18 samples were dated using radiocarbon dating method, among which 8 dates were obtained using AMS technique (Table 1).

The complete palynological analysis was conducted for the deepest log of the main peat bog (Fig. 5). Samples $1 \mathrm{cc}$ in volume, were taken for pollen analysis at intervals of $5 \mathrm{~cm}$. Samples were prepared according to the modified Erdtmann's acetolysis method (Erdtmann, 1943). The pollen sum, as a basis of calculation, includes all counted pollen types excluding pollen of aquatic plants

Table 1. Radiocarbon datings of the Pcim-Sucha1 peat bog (calibration using OxCal computer program v. 3.10 (Bronk-Ramsey, 1995; 2001 ) on the base of Reimer et al. (2004) calibration curve.

\begin{tabular}{|c|c|c|c|c|c|}
\hline $\begin{array}{l}\text { Depth } \\
{[\mathrm{cm}]}\end{array}$ & Material & Lab. Code & $\begin{array}{l}\text { Age }{ }^{14} \mathrm{C} \\
\text { (yrs BP) }\end{array}$ & $\begin{array}{l}\text { Calendar age } 2 \sigma \\
\text { (cal yr BC-AD) }\end{array}$ & Context of datings \\
\hline \multicolumn{6}{|c|}{$\log 1$} \\
\hline $37-45$ & Peat & Ki-11939 & $2410 \pm 60$ & $\begin{array}{l}760-680 \mathrm{BC} \\
670-390 \mathrm{BC}\end{array}$ & start of mineral horizon sedimentation \\
\hline $211-213$ & Wood & Ki-12199 & $5710 \pm 90$ & $4730-4350 \mathrm{BC}$ & $\begin{array}{l}\text { series of mineral (illuvial) horizons } \\
\text { deposition }\end{array}$ \\
\hline $283-290$ & Peat & IGSB-1092 & $7620 \pm 175$ & $7050-6050 \mathrm{BC}$ & mineral horizon sedimentation \\
\hline $315-322$ & Wood fragment & Ki-11940 & $8250 \pm 90$ & $7500-7060 \mathrm{BC}$ & start of peat accumulation \\
\hline \multicolumn{6}{|c|}{ Log 2 (AMS datings) } \\
\hline $18-20$ & $\begin{array}{c}\text { Macro-fossils: } \\
\text { seeds of Carex sp. }\end{array}$ & GdA-1326 & $209 \pm 28$ & $\begin{array}{l}1640-1690 \text { AD } \\
1730-1810 \text { AD } \\
1930-1960 \text { AD } \\
\end{array}$ & local pollen assemblage zones limit \\
\hline $30-31$ & $\begin{array}{c}\text { Macro- fossils } \\
\text { seeds of: } \\
\text { Rubus sp. Carex sp. }\end{array}$ & GdA-1308 & $34 \pm 26$ & $\begin{array}{l}1690-1730 \mathrm{AD} \\
1810-1850 \mathrm{AD} \\
1870-1920 \mathrm{AD} \\
1950-1960 \mathrm{AD}\end{array}$ & local pollen assemblage zones limit \\
\hline 35 & Wood fragment & Gd-30159 & $1850 \pm 80$ & $0-390 \mathrm{AD}$ & mineral horizon sediment. \\
\hline $60-65$ & Wood fragment & Gd-19178 & $2740 \pm 65$ & $1050-790 \mathrm{BC}$ & delivery of mineral sediments \\
\hline 105-106 & $\begin{array}{c}\text { Macro-fossils: } \\
\text { seeds of Rubus sp. }\end{array}$ & GdA-1309 & $3723 \pm 33$ & $\begin{array}{l}2280-2250 \mathrm{BC} \\
2210-2020 \mathrm{BC}\end{array}$ & local pollen assemblage zones limit \\
\hline $120-121$ & Macro-fossils & GdA-1327 & $4058 \pm 34$ & $\begin{array}{l}2850-2810 \mathrm{BC} \\
2700-2470 \mathrm{BC} \\
\end{array}$ & local pollen assemblage zones limit \\
\hline 195-196 & $\begin{array}{l}\text { Macro-fossils: } \\
\text { moss fragm. }\end{array}$ & GdA-1310 & $5056 \pm 36$ & $3960-3760 \mathrm{BC}$ & local pollen assemblage zones limit \\
\hline $235-236$ & $\begin{array}{l}\text { Macro-fossils: } \\
\text { seeds of Carex sp. }\end{array}$ & GdA-1328 & $6017 \pm 39$ & $5010-4790 \mathrm{BC}$ & local pollen assemblage zones limit \\
\hline $314-315$ & $\begin{array}{l}\text { Macro-fossils: } \\
\text { seeds of Carex sp. }\end{array}$ & GdA-1312 & $8173 \pm 42$ & $7310-7060 \mathrm{BC}$ & local pollen assemblage zones limit \\
\hline 343-344 & $\begin{array}{c}\text { Macro-fossils: } \\
\text { seeds of Carex sp. }\end{array}$ & GdA-1329 & $8385 \pm 50$ & $7570-7330 \mathrm{BC}$ & local pollen assemblage zones limit \\
\hline \multicolumn{6}{|c|}{$\log 3$} \\
\hline $287-297.5$ & Wood fragment & Ki-12452 & $8090 \pm 100$ & $7350-6650 \mathrm{BC}$ & start of peat accumulation \\
\hline \multicolumn{6}{|c|}{$\log 4$} \\
\hline $42.5-50$ & Peat & IGSB-1091 & $1900 \pm 115$ & 200BC-400AD & start of mineral horizon sedimentation \\
\hline $185-190$ & Peat & Ki-12202 & $4840 \pm 80$ & $\begin{array}{l}3790-3490 \mathrm{BC} \\
3460-3370 \mathrm{BC}\end{array}$ & $\begin{array}{c}\text { start of series of mineral horizons } \\
\text { sedimentation }\end{array}$ \\
\hline $260-270$ & Peat & Ki-12201 & $7410 \pm 80$ & $6430-6090 \mathrm{BC}$ & start of peat accumulation \\
\hline
\end{tabular}

KI-Kiev Radiocarbon Laboratory, Ukraine

IGSB - Mińsk Radiocarbon Laboratory, Belarus

$\mathrm{Gd}$ - (gas proportional dating technique), GdA - (AMS dating) Gliwice Radiocarbon Laboratory, Poland 
and spores (Fig. 5). For counting sporomorphs, drawing pollen diagram and implementing numerical analysis the POLPAL program were used (Walanus and Nalepka, 1999; Nalepka and Walanus, 2003). The subdivision of the Holocene chronozones is based on the climaticstratighraphic scale determined by Mangerud et al. (1974).

In the second peat bog (Pcim Sucha 2) occurring within the landslide zone one borehole log drilled with the peat sampler INSTORF were studied (Fig. 6). Three radiocarbon datings were carried out for this peat bog (Table 2).

\section{SEQUENCE OF DEPOSITS}

\section{Pcim Sucha 1}

The maximum depth of the main depression measured in boreholes in the central part of the peat bog is $3.75 \mathrm{~m}$ (Fig $3-\log 2$ ) The bottom of the depression is formed of mineral sediments ca $30 \mathrm{~cm}$ thick, sealing the basin. They are laminated due to the different content of organic material - irregular, thin (up to $1 \mathrm{~cm}$ ) layers or lenses of lighter mud are visible. The sediments are also slightly differentiated in granulometric composition: in the bottom part they are represented by sandy clayey silt $(\mathrm{Mz}=$ $6.7 \varphi)$ grading upward into silty clay $(\mathrm{Mz}=8.1 \varphi)$, while the top part is again formed of clayey silt (again $\mathrm{Mz}=6.7$ $\varphi)$. At the top of this layer charcoal fragments up to $1 \mathrm{~cm}$ in diameter were found (Figs. 3, 4). Above this mineral layer, the sequence of peat sediments started, which is shown on loss on ignition curve (Fig. 4). The lowermost part of this sequence (interval $3.4-3.0 \mathrm{~m}$ ) is formed of considerably decomposed peat with occasional fragments of Betula sp., Salix sp. (wood, bark), Bryales sp. as well as Carex sp. Bottom of this peat unit in the deepest log was dated by radiocarbon AMS method at $8385 \pm 50 \mathrm{BP}$ (7570-7330 cal BC, GdA-1329). In the neighboring logs the dates obtained from the analogous horizon range $8250 \pm 90$ BP $(7500-7060$ cal BC, Ki-11940) and $8090 \pm 100$ (7350-6650 cal BC, Ki-12452). In the marginal $\log$ the date from this horizon is younger $(7410 \pm 80 \mathrm{BP}$; 6430-6090 cal BC, Ki-12201) and indicate, that in the marginal parts of the depression the peat accumulation started later than in its central, deepest parts (Fig. 3 - log 4).

Above this lowermost peat unit, in the interval ca 2.4$2.9 \mathrm{~m}$, within the deepest $\log$ distinct decline of loss on ignition curve is visible, which is characteristic for supply of mineral material to the basin (Fig. 3 - $\log 2$; Fig. 4). In the interval $2.9-2.8 \mathrm{~m}$, thin mineral horizon is formed of silty sand $(\mathrm{Mz}=3.1 \varphi)$ poorly sorted $(\sigma 1=2.3)$, bearing rare organic material. In the upper part of this section (2.8-2.4 m) considerably decomposed and contaminated peat forms apparent illuvial horizon (macroscopically discernible - see right Photo on Fig. 4), with thin mineral insert $(5 \mathrm{~cm})$ at the top. The beginning of this illuvial horizon deposition was dated by radiocarbon between $8173 \pm 42$ BP $(7310-7060$ cal BC, GdA-1312) and $7620 \pm 175$ BP (7050-6050 cal BC) (IGSB-1092), whereas the date related to the end of the mineral material delivery was $6017 \pm 39$ BP $(5010-4790$ cal BC, GdA-1328) (Fig. 3, $\operatorname{logs} 1,2$ ).
Above the illuvial horizon, in the interval ca 2.4-0.8 $\mathrm{m}$, the thickest layer of woody osier peat in the sequence occurs. This peat contains 50-65\% of macrofossils (wood and leafs), mainly Salix sp., also Phragmites australis, Carex elongata and Carex sp., occasionally wood of Betula sp. In the uppermost part of this unit (1.2-0.8 m), apart from numerous fragments of Salix sp., wood and

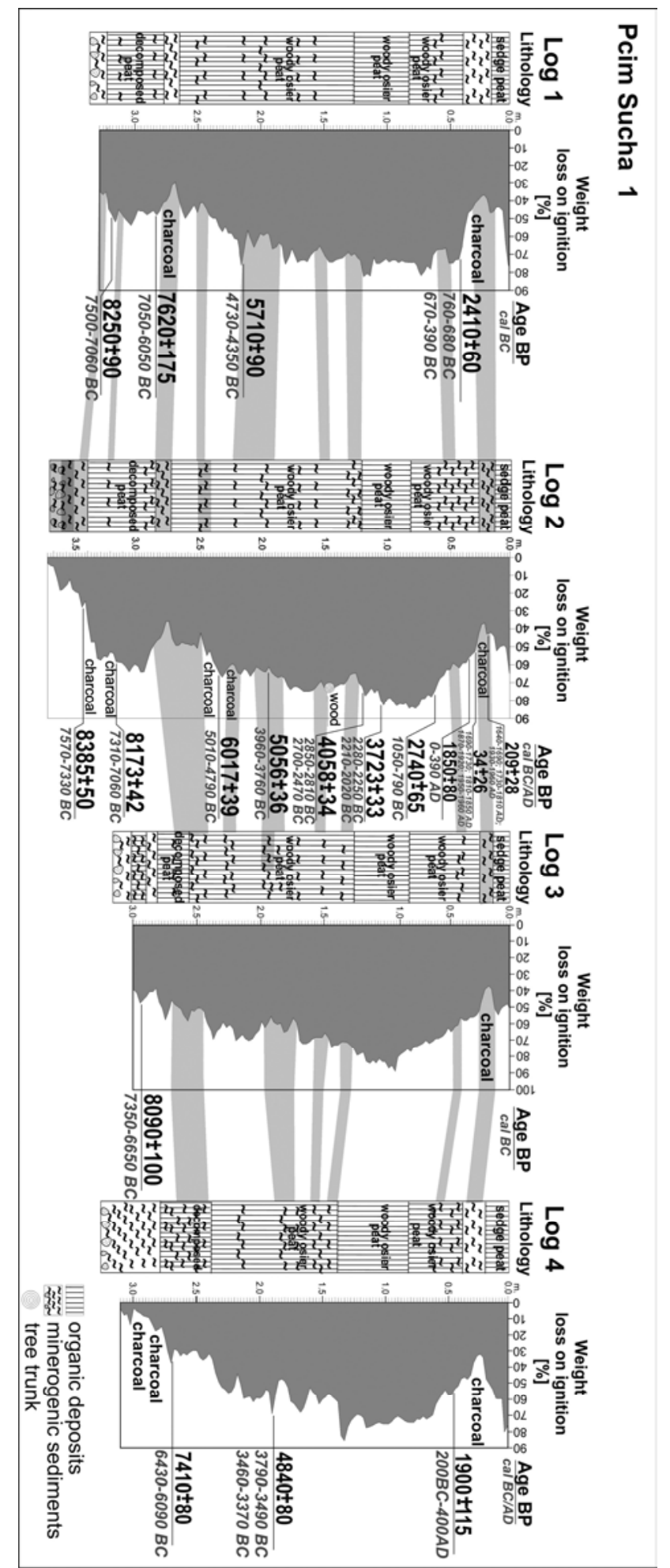

Fig. 3. Lithostratigraphic sequence of the Pcim-Sucha 1 peat bog with loss on ignition curves. Position of logs on the Fig. 2a (signatures and calibrations of datings - see Table 1). 
Table 2. Radiocarbon datings of the Pcim-Sucha1 peat bog (calibration using OxCal computer program v. 3.10 (Bronk-Ramsey, 1995, 2001) on the base of Reimer et al. (2004) calibration curve.

\begin{tabular}{|l|c|c|c|c|c|}
\hline $\begin{array}{l}\text { Depth } \\
\text { [cm] }\end{array}$ & Material & Lab. Code & $\begin{array}{c}\text { Age }{ }^{14} \mathrm{C} \\
\text { (yrs BP) }\end{array}$ & $\begin{array}{c}\text { Calendar age 2 } \sigma \\
\text { (cal yr BC-AD) }\end{array}$ & \multicolumn{2}{c|}{ Context of datings } \\
\hline $60-63$ & Wood fragment & Ki-7473 & $790 \pm 80$ & $\begin{array}{c}1030-1310 \mathrm{AD} \\
1360-1390 \mathrm{AD}\end{array}$ & start of mineral cover deposition \\
\hline $81-84$ & Wood, silt organic & Ki-7460 & $1070 \pm 65$ & $\begin{array}{c}770-1050 \mathrm{AD} \\
1080-1160 \mathrm{AD}\end{array}$ & peat below mineral cover \\
\hline $105-108$ & Wood, silt organic & Ki-7459 & $2040 \pm 60$ & $210 \mathrm{BC}-80 \mathrm{AD}$ & $\begin{array}{c}\text { start of deposition of contaminated } \\
\text { organic material }\end{array}$ \\
\hline
\end{tabular}

bark of Pinus silvestris and Betula sp. as well as remains of Menyanthes trifoliata, Phragmites australis and occasionally Carex sp. were found. The lower part of this unit (2.4-1.8 m) is strongly contaminated with mineral material (average loss on ignition ranges here $60 \%$ ). Several events of mineral material delivery to the basin are marked on loss on ignition curve before the date $5056 \pm 36$ BP (3960-3760 cal BC) (GdA-1310). The intensity of these supplies in the central part of the basin (the $\log 2$ ) is relatively less than in the marginal parts of the peat (other logs) (Fig. 3). Percentage of organic material increases upwards, reaching almost $85 \%$ loss on ignition in the uppermost part of this peat unit (Fig. 3 - $\operatorname{logs} 1,2$; Fig. 4). In the middle part of the osier peat unit (slightly above the depth of $1.5 \mathrm{~m}$ in the $\mathrm{w}$ main $\log$ ), the illuvial horizon is marked with ca $15 \%$ drop of loss on ignition curves (Fig. 4). Its top was dated at 4058 \pm 34 BP (2850-2810 and 2700-2470 cal BC, GdA-1327).
In the upper section of the depositional sequence loss on ignition curve shows characteristic decline (regression) suggesting gradual but accelerated delivery of allochthonous material to the basin. This process, commenced before the date $2740 \pm 65 \mathrm{BP}(1050-790$ cal BC, Gd-19178), was finalized with deposition of a mineral horizon composed of silty clayey sand $(\mathrm{Mz}=4.4-5.8 \varphi-$ Fig. 4) (locally, in marginal $\log \mathrm{Mz}=3.6 \varphi$ ). The thickness of this horizon varies in particular logs from ca 10 to 20 $\mathrm{cm}$. Within this horizon numerous small charcoal fragments were found (Fig. 3). Radiocarbon dates (obtained in different laboratories, using various material - see Table 1) connected with the beginning of the illuvial horizon sedimentation range $2410 \pm 60 \mathrm{BP}$ (760-680 and 670-390 cal BC, Ki-11939), 1850 \pm 80 BP (0-390 cal AD, Gd-30159) as well as $1900 \pm 115 \mathrm{BP}(200 \mathrm{cal} \mathrm{BC}-400 \mathrm{cal}$ AD, IGSB-1091) (Fig. 3, Table 1). Radiocarbon AMS dates related to the middle and top parts of this horizon
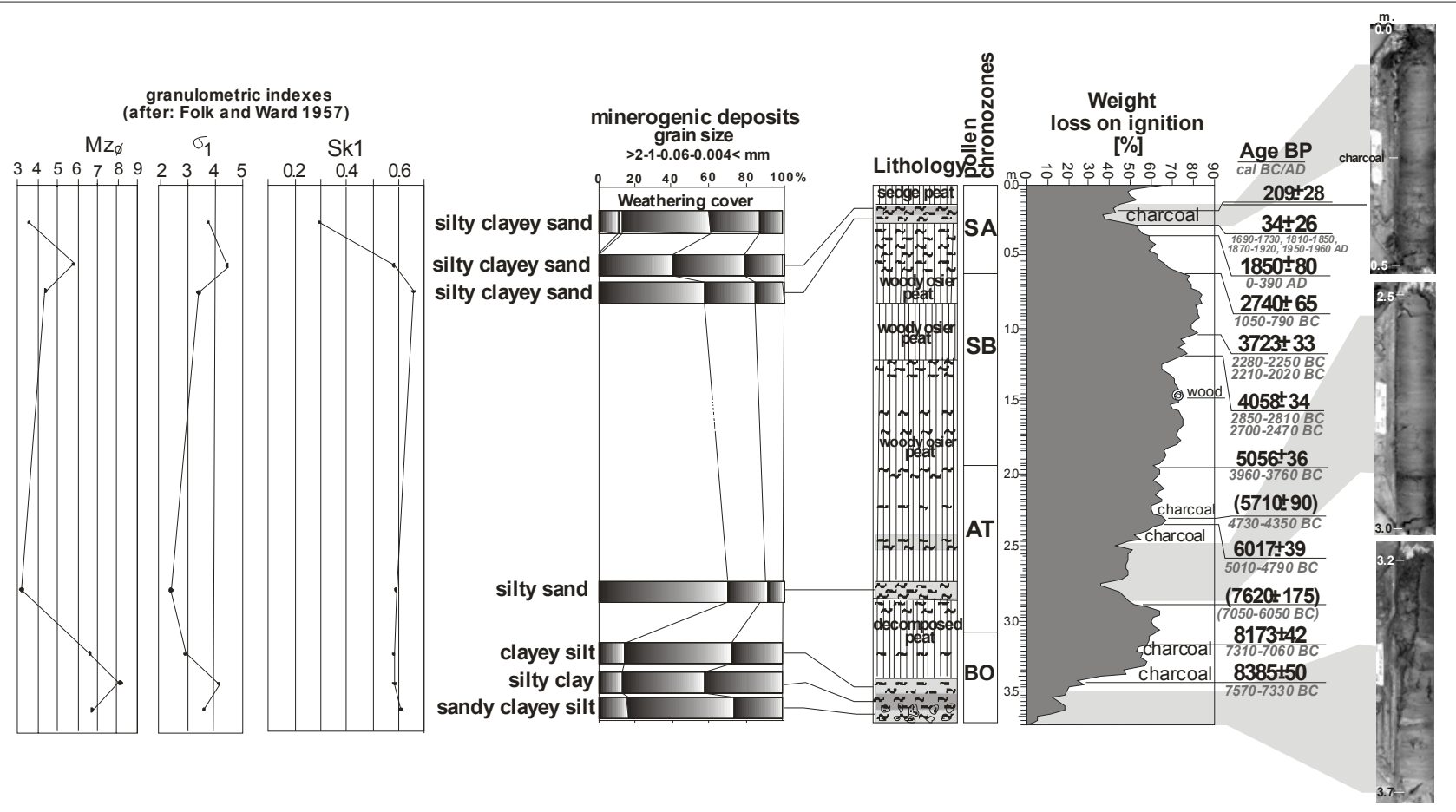

Fig. 4. Lithostratigraphic sequence of the main, central $\log$ (log 2 in Fig. 3) of the Pcim-Sucha 1 landslide peat bog showing types of peat and grain size (areometry) of minerogenic sediments with granulometric indexes (after: Folk and Ward 1957), and loss on ignition curves. Age BP/cal BC-AD exposed for the presented log and for correlation horizons of other logs (in brackets). On the photo: chosen fragments of the log (recovered by an Instorf sampler) with mineral horizons. Explanation of symbols is given in Fig.3. 
(34 $\pm 26 \mathrm{BP}, \mathrm{GdA}-1308$ and $209 \pm 28 \mathrm{BP}, \mathrm{GdA}-1326)$ give, after calibration, three possible time intervals of $95 \%$ probability, as follows: 1690-1730 cal AD, 1810-1850 cal AD, 1870-1920 cal AD and 1950-1960 cal AD (GdA$1308)$ as well as $1640-1690$ cal AD, $1730-1810$ cal AD and 1930-1960 cal AD (GdA-1326). It shows that inversion of dates visible in radiocarbon results is ostensible and suggests that uppermost $30 \mathrm{~cm}$ of depositional sequence accumulated during the last 350 years (Fig. $3-\log 2$ ).

Above this mineral horizon thin layer of sedge peat (10 cm thick) occurs, with numerous macrofossils of Carex rostrata, Carex gracilis, Carex paradoxa and Carex diandra.

\section{Pcim Sucha 2}

The maximum depth of the depression measured in boreholes was $1.3 \mathrm{~m}$. The organic sediments are highly contaminated with mineral material (Margielewski, 2006a). Upon the bottom layer occurring at the depth 1.3$1.1 \mathrm{~m}$ (sandy clayey silt, $\mathrm{Mz}=7.2 \varphi$ ) a thin horizon of silts abundant in organic material of decomposed peat (loss on ignition only 15-20\% - Fig. 6) lies. Within this unit only wood fragments of deciduous trees, contaminated with sand was found. The bottom of this mineralorganic unit was dated by radiocarbon method at $2040 \pm 60$ BP (210 cal BC-80 cal AD, Ki-7459), while its top part was dated at $1070 \pm 65 \mathrm{BP}$ (770-1050 and 1080$1160 \mathrm{cal} A D, \mathrm{Ki}-7460)$. This unit is overlain with mineral cover (interval $0.6-0.2 \mathrm{~m})$ formed of clayey silt $(\mathrm{Mz}=$ 6.8-7.7 $\varphi$ ). The beginning of its deposition was dated at $790 \pm 80$ BP (1030-1310 and 1360-1390 cal AD, Ki-7473). Upon this cover a layer of sedge peat ca $20 \mathrm{~cm}$ thick developed (Fig. 6).

\section{VEGETATION HISTORY}

The Pcim-Sucha 1 depositional sequence gives valuable information about the Holocene history of the Outer Carpathians because it comprises a continuous record of events, despite location of boreholes in the landslide depression. In such landslide peat bogs deposits are often irregular, with depositional breaks - hiatuses (Margielewski, 2001 and 2006a; Margielewski et al., 2003).

\section{Description of the Local Pollen Assemblage Zones (LPAZ)}

The pollen zones were distinguished using numerical methods CONSLINK and PCA. This analysis indicated boundaries of eight zones, which were characterized by predomination of particular taxa (Fig. 5).

SP-1, Corylus LPAZ (depth: below $3.20 \mathrm{~m}$ )

Rising curve of Corylus percentage reaches $30 \%$; the curve of Pinus extends $25 \%$ at the beginning, but rapidly drops at the end of this phase; within whole horizon continuous curve of Viscum occurs. At the end of the phase continuous curve of Fraxinus commences.

\section{SP-2, Corylus-Ulmus-Tilia LPAZ (depth: 3.20-2.65 m)}

The curve of Corylus avellana after the absolute maximum at the beginning of this zone drops below $20 \%$ during this phase; contents of Ulmus and Tilia extend

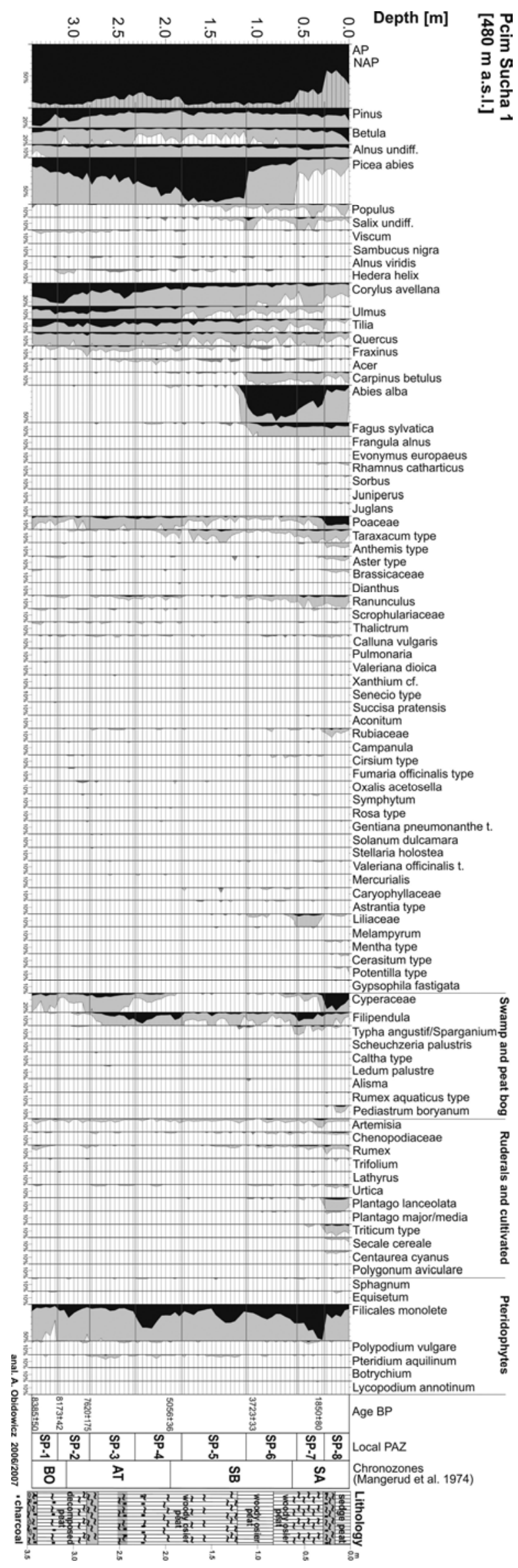

Fig. 5. Percentage pollen diagram of the Pcim-Sucha 1 peat bog (log 2 in Fig. 3), with lithological column (explanation of symbols is given in Fig. 3). Chronozones according to Mangerud et al., 1974. 
$10 \%$ in the whole zone. Hedera helix gains its maximum value, whereas Viscum is still represented by a continuous curve; the curve of Fraxinus reaches its absolute maximum at the end of this zone. At the end of this zone pollen of Typha angustifolia/Sparganium appears.

SP-3, Corylus-Tilia-Picea LPAZ (depth: 2.65-2.35 m)

At the end of this zone the curve of Corylus avellana extends $20 \%$ for the last time; the curve of Tilia ranges slightly higher value than in the previous zone; rising curve of Picea abies oscillates around $30 \%$. The beginning of the phase is connected with slight but perceptible scattering of forest surrounding the lake, probably caused by the lake expansion (Cyperaceae, Filipendula).

\section{SP-4, Picea-Corylus-Tilia LPAZ (depth: 2.35-1.80m)}

The curve of Picea abies systematically rises, extending 50\%; in turn the percentage of Corylus consequently declines, although ranging still above $10 \%$; value of Tilia ranges close to $10 \%$; Acer is characterized by a continuous curve reaching its maximum values in this zone. At the beginning of this phase the curve of Filicales monolete distinctly rises; also the curve of Filipendula gains its absolute maximum in this zone.

\section{SP-5, Picea LPAZ (depth: 1.80-1.15 m)}

The percentage of Picea abies reaches almost 70\%, proving that the spruce forest surrounds the peat bog. At the end of this horizon continuous curve of Abies alba commences; Taraxacum- type is represented by a continuous curve (valuing several percent) within this horizon.

SP-6, Abies LPAZ (depth: 1.15-0.55 m)

Pollen of Abies alba predominates, its curve extends $50 \%$; the curve of Picea abies distinctly drops below $20 \%$; the beginning of continuous curves of Carpinus betulus and Fagus sylvatica.

\section{SP-7, Abies-Fagus LPAZ (depth: 0.55-0.25 m)}

The beginning of the phase means the first signs of deforestation, marked by drops of Abies alba and definitely Picea abies curves. Likely also the water basin enlarges (Typha angustifolia/Sparganium).

SP-8, NAP LPAZ (depth. 0.25-0.00 m)

The sum of NAP increases even above $60 \%$. It is composed mainly of Cyperaceae, Poaceae as well as taxa representing ruderals and cultivated plants (e.g. Urtica, Plantago lanceolata, Centaurea cyanus, Triticum, Secale cereale).

\section{Changes in vegetation}

The history of vegetation recorded in the palynological sequence Pcim-Sucha 1 began in the Boreal chronozone, which is marked in various parts of the Carpathians by important role of hazel (Corylus avellana) (Fig. 5) (Ralska-Jasiewiczowa et al., 2004). This species is an indicator of the phase lasting the longest time, ca 8500$7300 \mathrm{BP}$, in the Podhale region, Inner Carpathians (Obidowicz, 1990). The increased percentage of Corylus was also observed in the higher mountains, in the Tatra Mts. (Obidowicz, 1996).

The Atlantic chronozone in the Western Carpathians is characterized by the occurrence of mixed deciduous forests of the riverside or dry-ground forest types, with Ulmus, Tilia, Quercus, Fraxinus as well as Alnus (likely mainly Alnus incana). In the youngest part of the Atlantic chronozone (SP-4), in the area of Pcim-Sucha Acer becomes more common (Fig. 5). During this whole phase the area covered by spruce forests enlarges, and this type of forest becomes common in the higher parts of the Western Carpathians, thus also in the Beskid Żywiecki Mts. and in some parts of the Tatra Mts. (Obidowicz, 1996, 2003). In the vicinity of the Pcim-Sucha site natural forest fires may have occurred (presence of Pteridium aquilinum) (Fig. 5). The role of these fires in slight but perceptible scattering of the forest near the water/depositional basin cannot be determined. This process could have been also stimulated by development of the wetland plant associations (Cyperaceae, Filipendula).

At the beginning of the Subboreal Phase, between ca. 5000 and 3700 BP, the forests in the area of Pcim-Sucha site were dominated by spruce (Picea abies) (Fig. 5). The percentage of spruce is so high, that dense forest undoubtedly surrounded the depositional basin. The abundance of morphological taxa of the Taraxacum type indicates the occurrence of meadow plant associations.

About 3700 BP sudden change in forest from spruce type to fir type took place. This process, lasting very

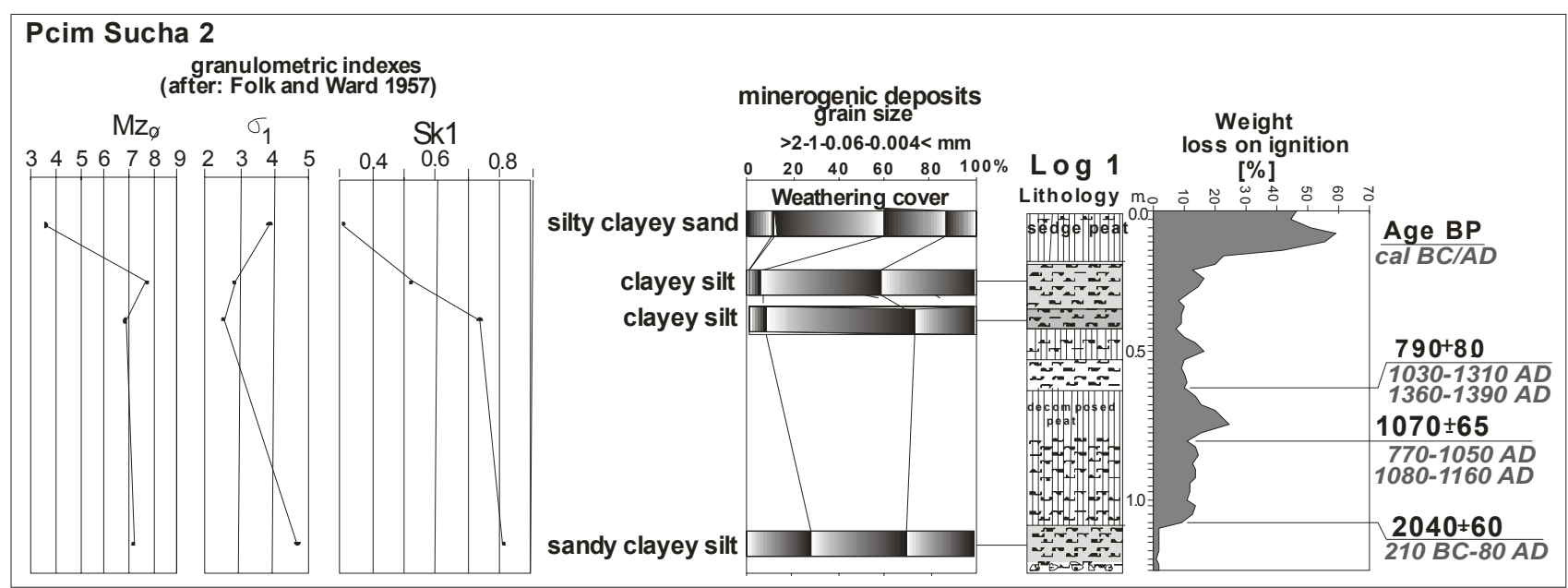

Fig. 6. Lithostratigraphic sequence of the Pcim Sucha 2 peat bog showing types of peat and grain size (areometry) of minerogenic sediments with granulometric indexes (after: Folk and Ward 1957). Signatures of datings - see Table 2. Explanation of symbols is given in Fig. 3. 
short time (not longer than 100-150 years), in the Podhale region is attributed to the date $3670 \pm 70 \mathrm{BP}$ (Obidowicz, 1990), while in the Beskid Makowski Mts. (Kamiennik peat bog) - to the date $3705 \pm 90$ BP (Margielewski, 2006a; Margielewski et al., 2010). The replacement of spruce by fir trees in the lower parts of the Tatra Mts. (Obidowicz, 1996) and in the Beskid Żywiecki Mts. took longer time (Obidowicz, 2003).

Since the beginning of the Subatlantic chronozone the forested area surrounding the Pcim Sucha 1 peat bog diminishes, what is mainly proved by the distinct drop of Abies alba percentage. The deforested areas become occupied by ferns (Filicales monolete). In the SP-7 zone the curve of Liliaceae is very specific, however the lack of identified species disables interpretation of this phenomenon.

After the date $1850 \pm 80 \mathrm{BP}$ the decrease of the forested area is very apparent and it is undoubtedly caused by human impact. It is confirmed by curves of taxa defined as a group of ,ruderals and cultivated plants”, especially Plantago lanceolata, Rumex, Urtica, Centaurea cyanus, Triticum, Secale cereale. Since the change at the boundary SP$7 / \mathrm{SP}-8$ is relatively large, a hiatus cannot be excluded in the depositional sequence above the horizon dated at $1850 \pm 80$ BP. The presence of Pediastrum boryanum indicates occurrence of an open water basin (Fig. 5).

\section{RECONSTRUCTION OF PALAEOENVIRON- MENTAL CHANGES}

Radiocarbon dates as well as palynological analysis indicate that the Pcim Sucha 1 peat bog began to form at the decline of the Boreal Phase. Development of the depositional basin and, consequently, the landslide process can also be connected with this Phase. Characteristic, laminated mineral sediment at the basin bottom suggests a dynamic deposition environment and, connected with it, rhythmic supplies of mineral material to the basin, typical of the humid period at the decline of the Boreal Phase (Starkel, 1999). At the bottom of the depositional sequence (also in the lowermost mineral unit sealing the basin floor) numerous charcoal fragments were found, however this fact can hardly refer to the activity of Mesolithic man. Forest fires, resulting in charcoal delivery to the sediments, could have been caused by natural reasons (see Clark, 1988). This question cannot be unequivocally judged by the occurrence of pollen of plants preferring open areas (Rumex, Artemisia, Chenopodiaceae, Poaceae), and even ruderal plants (Urtica) in the lowermost depositional section (Fig. 5). The appearance of open environment could have been a direct result of deforestation caused by recent landslide formation. Such a possibility was postulated in the sixties of the $20^{\text {th }}$ century by Franks and Johnson (1964). Phenomena of this type were also commonly recorded in the bottom sections of the depositional sequences of numerous landslide peat bogs in Polish Carpathians (Margielewski, 2006a).

At the beginning of the Atlantic Phase delivery of mineral material is marked by the illuvial horizon in peat with thin mineral layers at its bottom and top. Mineral deposits, forming locally several thin layers, represent high-energetic sediments (sensu Kotarba, 1996), charac- terized by significant percentage of sand fractions (Fig. 4). This illuvial horizon and mineral layers within it (differently marked in particular logs of the peat bog) are undoubtedly connected with impact of extreme hydrometeorological events, characteristic for climate cooling and moistening at the end of the Boreal Phase and the beginning of the Atlantic Phase (see Starkel, 1999). Humid climate at this time might be confirmed by the occurrence of pollen of aquatic (Typha angustifolia) and wetland plants (Caltha, Ledum) (Fig. 5).

Significant climate cooling in this time is observed worldwide. It caused Alpine glaciers' advance, called the Venediger Stage (Bortenschlager, 1982; Hormes et al., 2001). Pluvial equivalent of this process in the lower parts of mountains were intensive rains causing e.g. rising water table in sub-Alpine lakes (Joux phase - Magny, 1993) as well as extreme floods, among others floods of Upper Vistula River and its Carpathian tributaries (ca 8.77.8 ka BP) (Starkel et al., 1996 and 2006; Czyżowska, 1997; Starkel, 2002). The horizons of high-energetic sediments representing this period were registered in the Tatra Mts. lakes (Baumgart-Kotarba and Kotarba, 1993; Kotarba and Baumgart-Kotarba, 1997) as well as within the Carpathian peat bogs (Ralska-Jasiewiczowa, 1980). Similar changes in sedimentation were observed in landslide peat bog sequences of the Beskid Makowski Mts. (Margielewski et al., 2003, Margielewski, 2006a). In the proximity of the Pcim-Sucha site, analogous, thick mineral horizon (with similar high percentage of sand fraction) related to significant humid climate at the beginning of the Atlantic Phase was found e.g. in the sequence of the Bogdanówka landslide peat bog in the Beskid Makowski Mts. (Margielewski, 2006a). In turn, in the landslide peat bog at the Mt. Koton (also the Beskid Makowski Mts.), thick mineral cover started to form upon the peat deposits at the beginning of the early Atlantic humid period (Margielewski et al., 2003). Distinct intensification of gravitational mass movements in the Carpathians (Gil et al., 1974; Alexandrowicz, 1996 and 1997; Starkel, 1997; Margielewski, 1998) and other European mountains (Soldati et al., 2004) was connected with this humid period.

Within the illuvial horizon, charcoal fragments, several millimeters in size were found at various depths. However, pollen diagrams insufficiently prove unequivocal anthropogenic origin of these coal fragments. Only occasionally and in some places pollen of Rumex, Urtica and Chenopodiaceae occurs, and also an increase of herbaceous plants (NAP) in relation to tree pollen (AP) as well as regression of Picea abies pollen curve (and less conspicuous regression of Ulmus curve) are observed (Fig. 5). Therefore the activity of Mesolithic man related to seasonal pasturing and forest burnout for fertilizing cannot be excluded (see Valde-Nowak, 1995). In this case human impact connected with burnout of the forest and its undergrowth generating soil erosion could have stimulated intensification of delivery of mineral material to the peat bog (Starkel, 1988; Zolitschka et al., 2003).

Above the illuvial horizon, within the upper, Atlantic section of the sequence, local increase of mineral material percentage, dated at 5010-4790 cal BC, is shown in loss on 
ignition curve. More or less distinct variations in the loss on ignition curves observed in all logs after this event indicate frequent supplies of mineral material to the basin (Fig. 3). The explicitness of these events differs in particular logs (Fig. 3). This process, gradually finalized above the horizon dated at 5056 $\pm 36 \mathrm{BP}$ (3960-3760 cal BC), was connected with intensive cool and humid climate at the end of the Atlantic Phase and the beginning of the Subboreal Phase (Fig. 5). The beginning of the Subboreal Phase (palynologically identified) is marked in the sequences with continuation of the mineral material supply typical for the beginning of the Late Holocene (Figs. 3, 4).

The climate cooling at this time, causing advance of Alpine glaciers (Rotmoos/Piora Stage: ca 5300-4900 BP - see Bortenschlager, 1982; Hormes et al., 2001) as well as Scandinavian glaciers (Karlen and Kuylenstierna, 1996), resulted in common increase of climate humidity in the lower areas (Starkel, 1995). Consequently, the intensive rains generated rising water table in lakes of the sub-Alpine region (Magny, 1993 and 2004) and northern Poland (Ralska-Jasiewiczowa, 1989; Żurek and Pazdur, 1999). Especially conspicuous phase of the fluvial activity of the Upper Vistula River and its Carpathian tributaries was recorded in the period ca 5500-4900 BP (Starkel et al., 1996 and 2006; Starkel, 2002). Within this time span the phase of significant increase of mass movements was observed in the Carpathians (Alexandrowicz, 1996; Starkel, 1997; Margielewski, 1998) as well as in other mountain ranges of Europe (Ballantyne, 2002; Dapples et al., 2002; Soldati et al., 2004). In the landslide peat bog sequences of the Beskid Makowski Mts. distinct lithological changes, suggesting humid climate are marked. Numerous mineral horizons and mineral covers (of peat sediments) were thus deposited, or - on the other hand - the depositional basins were opened and drained, which resulted in removing of part of sediments producing hiatuses within depositional sequences (Margielewski and Zernitskaya, 2003; Margielewski et al., 2003; Margielewski, 2006a).

The next very important decrease in the loss on ignition curves is related to deposition of illuvial sediments observed in the main $\log$ (Fig. 4). This horizon is dated at less than 4058 \pm 34 BP (2850-2810 and 2700-2470 cal $\mathrm{BC}$ ), while in the other logs its explicitness on the loss on ignition curves is differentiated (the most distinct illuvial horizon is in the peripheral log: Fig. $3-\log 4$ ). This horizon is evidently connected with the next humid period at the beginning of the Subboreal Phase, reflected e.g. by the increase of fluvial activity of the Upper Vistula River and its Carpathian tributaries ca 4500-4100 BP (Starkel et al., 1996; Starkel, 2002). The subsequent, slight variations in the loss on ignition curve, related to the smaller supply of allochtonous material to the basin can be correlated with the next short period of humid climate and cooling falling on the Subboreal Phase decline ca 3.5-3.0 ka BP (Bortenschlager, 1982; Starkel, 1990; Starkel et al., 1996 and 2006, Hormes et al., 2001).

Characteristic, continuous regression marked in the loss on ignition curves in the upper sections of all logs was connected with gradual, although consequently increasing delivery of allochtonous material to the peat bog, undoubtedly generated by increased in climate humidity
(Figs. 3, 4). The beginning of the process of formation of a thick illuvial horizon, characterized by progressively increasing content of mineral material in the peat, took place slightly before the date $2740 \pm 65 \mathrm{BP}(1050-790 \mathrm{cal}$ $\mathrm{BC})$. Delivery of mineral material was finalized by deposition of a $10-20 \mathrm{~cm}$ thick mineral horizon. This layer, dated at the bottom part at $1850 \pm 80 \mathrm{BP}(0-390$ cal AD) (in the other logs: $1900 \pm 115 \mathrm{BP}$ and $2410 \pm 60 \mathrm{BP}$ ), is formed of silty clayey sand, thus-high energetic sediment, characterized by sand percentage similar to the slope covers (Fig. 4). The beginning of progressive delivery of allochtonous material to the peat bog was undoubtedly connected with extremely strongly increased climate humidity at the end of the Subboreal Phase and especially at the beginning of the Subatlantic Phase (Figs. 3, 5) (see Starkel, 1990). Climate cooling and moistening in this period caused the next phase of Alpine glaciers' advance (Goeschener 1 Stage - Bortenschlager, 1982; Hormes et al., 2001) as well as distinct increase of fluvial activity of Upper Vistula River and its tributaries noticed ca 23501800 BP (Klimek, 1988; Starkel et al., 1996; Starkel, 2002). A rise of water level in lakes of the subalpine zone (Magny, 1993 and 2004) and in the northern Polish territory (Ralska-Jasiewiczowa, 1989) was also observed. Intensive deposition of high-energetic material in lakes of the Tatra Mts. was recorded, too (Baumgart-Kotarba and Kotarba, 1993). Significant escalation of gravitational mass movements in the Carpathians (Alexandrowicz, 1996; Margielewski, 1998 and 2006a) as well as in other mountain ranges in Europe (Ballantyne, 2002; Dapples et al., 2002; Soldati et al., 2004) is also attributed to this period.

Gradual, progressive delivery of allochtonous material to the peat bog commenced at the turn of the Subboreal Phase and the beginning of the Subatlantic Phase finalized with deposition of mineral horizon is not specific for the Pcim-Sucha 1 site. Characteristic trend of loss on ignition curves within this time span was observed in logs of several other landslide peat bogs in the Beskid Makowski Mts. (Margielewski, 2006a; Margielewski et al., 2010).

Since the beginning of this mineral horizon deposition anthropogenic indicators have continuously occurred in the palynological diagram (at the depth ca $30 \mathrm{~cm}$ ) of the Pcim Sucha 1 peat bog sequence (Fig 5). They are represented by continuous pollen curves of cereals (Triticum, Secale cereale), weeds (Centaurea cyanus) and ruderal plants (Urtica) as well as plants preferring open habitats (Plantago lanceolata, Rumex, Poaceae). Also charcoal fragments are numerous in this section of depositional sequence, while the significant drop of tree pollen curves in the palynological diagram indicates intensive deforestation (Fig. 5). As mentioned above, the bottom of mineral horizon (and anthropogenic features connected with it) was dated by radiocarbon in various logs at $1850 \pm 80$ $\mathrm{BP}$ (0- 390 cal AD), $2410 \pm 60 \mathrm{BP}$ (760-680 and 670-390 cal BC) as well as $1900 \pm 115 \mathrm{BP}$ (200 cal BC-400 cal AD) (Fig. 3; Table 1). The beginning of permanent and intensive agricultural activity of man on the landslide flats can be undoubtedly attributed to the colonization of the Przeworsk Culture (200 BC - AD 450) commonly using the forest burnout technique for cereals' (preferably 
rye Secale cereale) cultivation (Madyda-Legutko, 1996). Some anthropogenic features (Triticum, Plantago lanceolata) occasionally occurred also earlier (below the described mineral horizon), suggest that the earlier phases of colonization (e.g. La Tène Culture) could have taken place in the proximity of the site (Figs. 4, 5). Consequently, high-energetic character of sediments was influenced by both climatic (more humid climate at the beginning of the Subatlantic Phase) and anthropogenic factors seen as evidences of burnout and intensive cultivation on the landslide flats (see Margielewski, 2000). Similar characteristic changes in sediments caused both by humid climate and human impact are commonly recorded in alluvia of south-Polish rivers (Klimek, 1988; Starkel et al., 1996; Kalicki, 1997; Dobrzańska and Kalicki, 2003).

The distribution of radiocarbon dates in the upper section of the sequence suggests that deposition of thin mineral horizon could have lasted relatively long time. The bottom of this horizon at the depth of ca $35 \mathrm{~cm}$ was dated at $1850 \pm 80 \mathrm{BP}(0-390$ cal AD), while the date obtained from the depth of $30-31 \mathrm{~cm}$ values $34 \pm 26 \mathrm{BP}$ (1690$1730,1810-1850,1870-1920,1950-1960 \mathrm{cal} \mathrm{AD})$, and at the depth of $18-20 \mathrm{~cm}-209 \pm 28$ BP (1640-1690; 1730$1810 ; 1930-1960$ cal AD). However, regarding intensive human impact, which generated accelerated delivery of mineral material, this seems to be impossible. Specific distribution of dates can be caused by break of sedimentation - hiatus in this section of depositional sequence, which is also suggested by rough changes in pollen associations observed in bottom parts of the mineral horizon (Fig. 5, see chapter 6). The commence of mineral horizon deposition was thus undoubtedly connected with more humid climate in the early Subatlantic, whereas the distribution of the youngest dates can indicate that part of sediments was removed during periods with increased precipitation and cooling in the Little Ice Age (ca AD 1550-1850 - see Grove, 1988). Probably in this period the basin was temporarily open and part of the older sediments of the Subatlantic Phase was eroded and removed to the deeply incised stream valley (see Fig. 2a) and, subsequently, the younger part of the mineral horizon was deposited and covered with thin layer $(10 \mathrm{~cm})$ of sedge peat recently accumulated.

During the early Subatlantic humid climate period the western part of the Pcim-Sucha landslide zone was modified by a younger generation of mass movements (Pcim Sucha 2) (Fig. 2a, c). This is proved by the oldest date, $2040 \pm 60$ BP ( 210 cal BC- 80 cal AD), from the bottom of the depositional sequence of the second, younger peat bog (Fig. 6). This date is accurately correlated with the beginning of deposition of the top mineral horizon in the older peat bog (Pcim-Sucha 1- see Fig. 3): also relatively high sand percentage in the bottom sediments of the younger peat bog suggests their high-energetic character (Fig. 6). Predominant mineral material percentage in depositional sequence of the younger peat bog seems to be a logical consequence of palaeoenvironmental changes within the landslide. It is a result of coincidence between climate changes and human impact, connected with agricultural use of landslide flats at this time (see Fig. 5). The beginning of mineral cover (clayey silt) formation upon the organic sediments, dated between $1070 \pm 65 \mathrm{BP}(770$ $1050,1080-1160$ cal AD) and 790 \pm 80 BP (1030-1310, 1360-1390 cal AD), could have been connected with humid climate during $10^{\text {th }}-11^{\text {th }}$ Centuries (Starkel, 1990; Starkel et al., 1996 and 2006). Subsequent stage of the mineral deposition, preceded by local and short increase of organic material in the sequence, can be attributed to the climatic pessimum of the Little Ice Age. The mineral horizon is covered by sedge peat (Fig. 6).

\section{CONCLUSIONS}

Climate changes of the Middle and Late Holocene were recorded in depositional sequences of the PcimSucha -1 landslide peat bog. Perfect time correlation of boundaries of the palynological chronozones with radiocarbon dating enables precise description of the connection between lithological changes and climatic phases. Apparent lithological changes symptomatic for intensive humid climatic periods (supply of high energetic sediments to the basin) were marked in a sequence of the older peat bog at the upper part of the Boreal Phase (laminated sediment), at the transition of the Boreal to the Atlantic Phases (horizon of high-energetic sediment within peat) as well as at the transition of the Subboreal to Subatlantic Phases, when the consequent delivery of mineral, allochthonous material to the peat bog commenced. This last humid climate period ended in the lower Subatlantic with deposition of a characteristic mineral horizon. Less distinct records (illuvial horizons in peat) of humid climate are in the early Subboreal and in the middle Subboreal Phase.

Characteristic lithological changes within the depositional sequence, appearing since the transition of the Subboreal to the Subatlantic Phases, were partly generated by activity of prehistoric man, strictly agriculture (Przeworsk Culture), recorded in the palynological diagram. During the early Subatlantic climate moistening the landslide zone was rejuvenated and the second sedimentary basin, filled with predominantly mineral sediments, formed. Deposition of this mineral horizon is attributed to a humid and cool climate during the early Middle Ages and the Little Ice Age.

Analysis of the sediments of the Pcim-Sucha landslide peat bogs unequivocally proves that landslide peat bogs are very sensitive indicator of changes in palaeoenvironment in the mountainous areas during the Holocene.

\section{ACKNOWLEDGEMENTS}

The study was performed in a frame of project granted by the Ministry of Science No 3P04E 01524 and statutory works of the Institute of Nature Conservation Polish Academy of Sciences. AMS radiocarbon dating was supported by the Silesian University of Technology habilitation (postdoctoral) project No BW/RGH-7/RMF0/2008. The authors wish to thank to Dr Krzysztof Lipka from the Agriculture University in Cracow for his help with interpretation of peat sediments and also to Dr Francois de Vleeschouwer for a great help with finding and identification of macrofossils dated by AMS. 


\section{REFERENCES}

Alexandrowicz SW, 1996. Holoceńskie fazy intensyfikacji procesów osuwiskowych w Karpatach (Stages of increased mass movements in the Carpathians during the Holocene). Kwartalnik AGH Geologia 22(3): 223-262 (in Polish, English summary).

Alexandrowicz SW, 1997. Holocene dated landslides in the Polish Carpathians. In: Frenzel B, ed., Rapid mass movement as a source of climatic evidence for the Holocene. Palaeoclimate Research 19: 75-83.

Ballantyne C, 2002. Debris flow activity in the Scottish Highlands: temporal trends and wider implications for dating. Studia Geomorphologica Carpatho-Balcanica 36: 7-27.

Battaglia S, Leoni L and Sartori F, 2002. Mineralogical and grain size composition of clays developing calanchi and biancane erosional landforms. Geomorphology 49: 153-170.

Baumgart - Kotarba M and Kotarba A, 1993. Późnoglacjalne i holoceńskie osady z Czarnego Stawu Gąsienicowego w Tatrach (Late Glacial and Holocene lacustrine sediments of the Lake Czarny Staw Gąsienicowy in the Tatra Mountains). Dokumentacja Geograficzna 4-5: 9-30 (in Polish, English summary).

Bortenschlager S, 1982. Chronostratigraphic Subdivision of the Holocene in the Alps. Striae 16: 75-79.

Bronk Ramsey C. 1995. Radiocarbon calibration and analysis of stratigraphy; the OxCal program. Radiocarbon 37(2): 425-430.

Bronk Ramsey C. 2001. Development of the radiocarbon calibration program. Radiocarbon 43(2A): 355-363.

Burtan J, 1977. Szczegółowa mapa geologiczna Polski 1: 50 000, arkusz Mszana Dolna (Detailed Geological Map of Poland, 1:50 000, sheet Mszana Dolna). Wydawnictwa Geologiczne, Warszawa.

Burtan J, 1978. Objaśnienia do szczegółowej mapy geologicznej Polski 1: 50 000, arkusz Mszana Dolna (Explanations for Detailed Geological Map of Poland, 1:50 000, sheet Mszana Dolna). Wydawnictwa Geologiczne, Warszawa: 70 pp. (in Polish).

Clark JS, 1988. Particle motion and the theory of charcoal analysis: source area, transport, deposition, and sampling. Quaternary Research 30: $67-80$.

Czernik J and Goslar T, 2001. Preparation of graphite targets in the Gliwice radiocarbon laboratory for AMS ${ }^{14} \mathrm{C}$ dating. Radiocarbon 43(2A): 283-291.

Czyżowska E, 1997. Record of the flood events in the alluvial fan sediment at Podgrodzie during the Boreal and Atlantic period. Dokumentacja Geograficzna 5: 1-76 (in Polish, English summary).

Dapples F, Lotter AF, Van Leeuwen J F N, Van Der Knapp WO, Dimitriadis S and Oswald D, 2002. Palaeolomnological evidence for increased landslide activity due to forest clearing and land-use since $3600 \mathrm{cal}$ BP in the western Swiss Alps. Journal of Palaeolimnology 27: 239-248.

Dikau R, Brunsden D, Schrott L and Ibsen ML, eds. 1996. Landslide recognition. Identification, Movement and Causes. J. Wiley \& Sons: $251 \mathrm{pp}$.

Dobrzańska H, and Kalicki T, 2003. Man and environment in the Vistula River Valley near Cracow from the $1^{\text {st }}$ to the $7^{\text {th }}$ Century AD. Archeologia Polski 48(1-2): 25-55 (in Polish, English summary).

Erdtmann G, 1943. An introduction to Pollen Analysis. Chronica Botanica, Waltham, Massachussets: $230 \mathrm{pp}$

Franks JW and Johnson RH, 1964. Pollen analytic dating of a Derbyshire landslip: the Cown Edge landslides, Charlesworth. New Phytologist 63(2): 209-216.

Folk RI and Ward WC, 1957. Brazos River bar: a study in the significance of grain size parameters. Journal Sedimentary Petrology 27(1): 3-26.

Gil E, Gilot E, Szczepanek K, Kotarba A and Starkel L, 1974. An Early Holocene landslide in the Beskid Niski and its significance for palaeogeographical reconstructions. Studia Geomorphologica Carpatho-Balcanica 8: 69-83.

Goslar T, Czernik J and Goslar E, 2004. Low-energy ${ }^{14} \mathrm{C}$ AMS in Poznań Radiocarbon Laboratory, Poland. Nuclear Instruments and Methods in Physics Research Section B: Beam Interactions with Materials and Atoms 223-224: 5-11.

Grove J, 1988. The Little Ice Age. London-New York, Methuen: 479 pp.

Hormes A, Müller B and Schlüchter C, 2001. The Alps with little ice: evidence for eight Holocene phases of reduced glacier extent in the Central Swiss Alps. The Holocene 11(3): 255-265.

Heiri O, Lotter AF and Lemcke G, 2001. Loss on ignition as a method for estimating organic and carbonate content in sediments: repro- ducibility and comparability of results. Journal of Paleolimnology 25: 101-110.

Karlen W and Kuylenstierna J, 1996. On solar forcing on Holocene climate: evidence from Scandinavia. The Holocene 6(3): 359-365.

Kalicki T, 1997. The reflection of climatic changes and human activity on sediments of small Forecarpathian tributaries of the Vistula River near Cracow, Poland. Studia Geomorphologica CarpathoBalcanica 31: 130-141.

Klimek K, 1988. An early Anthropohenic Alluviation in the Subcarpathian Oświęcim Basin, Poland. Bulletin of the Polish Academy of Sciences, Earth Sciences 36(2): 159-169.

Kotarba A, 1996. Sedimentation rate in the High Tatra Lakes during the Holocene - geomorphic interpretation. Studia Geomorphologica Carpatho-Balcanica 30: 51-56.

Kotarba A and Baumgart-Kotarba M, 1997. Holocene debris flow activity in the light of lacustrine sediment studies in the High Tatra Mountains, Poland. In: Frenzel B, ed., Rapid mass movement as a source of climatic evidence for the Holocene. Palaeoclimate Research 19: 147-158.

Magny M, 1993. Holocene fluctuation of lake levels in the French Jura and sub-Alpine ranges, and their implications for past general circulation pattern. The Holocene 3(4): 306-313.

Magny M, 2004. Holocene climatic variability as reflected by mid European lake-level fluctuation and its probable impact on prehistoric human settlements. Quaternary International 113: 65-79.

Madyda-Legutko R, 1996. Zróżnicowanie kulturowe polskiej strefy beskidzkiej $w$ okresie lateńskim $i$ rzymskim (Cultural diversity of Polish Beskidy Zone during La Tene and Roman Periods). Wydawnictwa Uniwersytetu Jagiellońskiego, Kraków: 166 pp. (in Polish).

Mangerud J, Andersen ST, Berglund BE, and Donner J, 1974. Quaternary stratigraphy of Norden, a proposal for terminology and classification. Boreas 3:109-126

Margielewski W, 1998. Landslide phases in the Polish Outer Carpathians and their relation to climatic changes in the Late Glacial and the Holocene. Quaternary Studies in Poland 15: 37-53.

Margielewski W, 2000. Economical role of the landslides in the Beskid Makowski Mts. Problemy Zagospodarowania Ziem Górskich 46: 15-34 (in Polish, English summary).

Margielewski W, 2001. Late Glacial and Holocene climatic changes registered in forms and deposits of the Klaklowo landslide (Beskid Średni Range, Outer Carpathians). Studia Geomorphologica Carpatho-Balcanica 35: 63-79

Margielewski W, 2006a. Records of the Late Glacial-Holocene palaeoenvironmental changes in landslide forms and deposits of the Beskid Makowski and Beskid Wyspowy Mts. area (Polish Outer Carpathians). Folia Quaternaria 76: 1-149.

Margielewski W, 2006b. Structural control and types of movements of rock mass in anisotropic rocks: case studies in the Polish Flysch Carpathians. Geomorphology 77(1-2): 47-68.

Margielewski W and Zernitskaya V, 2003. Late Glacial-Holocene palaeoenvironmental evidence recorded in the Hajduki peat bog (Beskid Sredni Mts, Outer Western Carpathians). Folia Quaternaria 74: 57-73.

Margielewski W, Obidowicz A and Pelc S, 2003. Late Glacial Holocene peat bog on Kotoń Mt. and its significance for reconstruction of palaeoenvironment in the Western Carpathians (the Beskid Makowski Range, South Poland). Folia Quaternaria 74: 35-56.

Margielewski W, Krapiec M, Valde-Nowak P and Zernitskaya V, 2010. A Neolithic yew bow in the Polish Carpathians. Evidence of the impact of human activity on mountainous palaeoenvironment from the Kamiennik landslide peat bog. Catena 80: 141-153

Mastella L, Zuchiewicz W, Tokarski AK, Rubinkiewicz J, Leonowicz P and Szczęsny R., 1997. Application of joint analysis for paleostress reconstructions in structurally complicated settings: case study from Silesian Nappe, Outer Carpathians, Poland. Przegląd Geologiczny 45: 1064-1066.

Mycielska-Dowgiałło E and Rutkowski J, eds., 1995. Researches of Quaternary sediments. Some methods and interpretation of the results. Warszawa, Wydział Geografii i Studiów Regionalnych UW: 356 pp. (in Polish).

Nalepka D, and Walanus A, 2003. Data processing in pollen analysis. Acta Palaeobotanica 43(1): 125-134.

Obidowicz A, 1990. Eine pollenanalytische und moorkundliche studie zür vegetationsgeschichte des Podhale-Gebietes (West Karpaten). Acta Palaeobotanica 30 (1-2): 147-219 (in German). 
Obidowicz A, 1996. A Late Glacial - Holocene history of the formation of vegetation belts in the Tatra Mts. Acta Palaeobotanica 36(2): 159-206.

Obidowicz A, 2003. The Holocene development of forest in the Pilsko Mt. area (Beskid Żywiecki Range, South Poland). Folia Quaternaria 74 : 7-15

Obidowicz A and Margielewski W, 2008. Problematyka klasyfikacji torfowisk górskich (Problems of mountainous peat bogs classification). In: Żurek S, ed., Torfowiska gór i Wyżyn. Uniwersytet in. J. Kochanowskiego, Kielce :103-109 (in Polish).

Pettijohn FJ, 1975. Sedimentary Rocks. 3rd ed. New York, Harper and Row: 628 pp.

Ralska-Jasiewiczowa M, 1980. Late Glacial and Holocene vegetation of the Bieszczady Mts (Polish Eastern Carpathians). Acta Palaeobotanica 20: 1-202.

Ralska-Jasiewiczowa M, ed., 1989. Environmental changes recorded in lakes and mires of Poland during the last 13000 years, Part III. Acta Palaeobotanica 29: 1-120.

Ralska-Jasiewiczowa M, Latałowa M, Wasylikowa K, Tobolski K, Madeyska E, Wright HE Jr. and Turner C, eds., 2004. Late Glacial and Holocene history of vegetation in Poland based on isopollen maps. W. Szafer Institute of Botany, Polish Academy of Sciences, Kraków: 444 pp.

Reimer PJ, Baillie MGL, Bard E, Bayliss A, Beck JW, Bertrand C, Blackwell PG, Buck CE, Burr G, Cutler KB, Damon PE, Edwards RL, Fairbanks RG, Friedrich M, Guilderson TP, Hughen KA, Kromer B, McCormac FG, Manning S, Bronk Ramsey C, Reimer RW, Remmele S, Southon JR, Stuiver M, Talamo S, Taylor FW, van der Plicht J and Weyhenmeyer CE, 2004. IntCal04 terrestrial radiocarbon age calibration, 0-26 Cal Kyr BP. Radiocarbon 46: 1029-1058.

Soldati M, Corsini A and Pasuto A, 2004. Landslides and climate change in the Italian Dolomites since the Late Glacial. Catena 55: 141-161.

Starkel L, 1988. Działalność człowieka jako przyczyna zmian procesów denudacji i sedymentacji w holocenie (Man's activity as a cause of changes of denudation and sedimentation processes in the Holocene). Przeglad Geograficzny 60: 251-265 (in Polish, English summary).

Starkel L, 1990. Holocen jako interglacjał - problemy stratygrafii (Holocene as interglacial - problems of stratigraphy). Przeglad Geologiczny 38: 13-16 (in Polish, English summary).

Starkel L, 1995. The pattern of the Holocene climatic variations in Central Europe based on various geological records. Quaestiones Geographicae, Special Issue 4: 259-264.

Starkel L, 1997. Mass movement during the Holocene: Carpathian example and the European perspective. In: Frenzel B., ed., Rapid mass movement as a source of climatic evidence for the Holocene. Palaeoclimate Research 19: 385-400.

Starkel L, 1999. 8500-8000 yrs BP Humid Phase - Global or regional? Science Reports of Tohoku Univ., $7^{\text {th }}$ Series (Geography) 49(2) (Special Issue on GLOCOPH '98): 105-133.

Starkel L, 2002. Change in the frequency of extreme events as the indicator of climate change in the Holocene (in fluvial systems). Quaternary International 91: 25-32.

Starkel L, Kalicki T, Krąpiec M, Soja R, Gębica P and Czyżowska E, 1996. Hydrological changes of valley floor in the Upper Vistula Basin during Late Vistulian and Holocene. In: Starkel L., ed., Evolution of the Vistula river Valley during the last 15000 years, p. IV. Geographical Studies Special Issue 9: 1-128.

Starkel L, Soja R and Michczyńska DJ, 2006. Past hydrological events reflected in Holocene history of Polish Rivers. Catena 66: 24-33.

Tołpa S, Jasnowski M and Pałczyński A, 1971. New classification of peats based on phytosociological methods. Bulletin International Peat Society 2: 9-14.

Valde-Nowak P, 1995. Osadnictwo wczesnorolnicze średniogórza niemieckiego (Early agricultural colonisation of German „Mittelgebirge"). Kraków, IAiE PAN: 191 pp. (in Polish).

Walanus A and Nalepka D, 1999. POLPAL. Program for counting pollen grains, diagrams plotting and numerical analysis. Acta $\mathrm{Pa}$ laeobotanica, Suppl. 2: 659-661

Wentworth CK, 1922. A scale of grade and class terms for clastic sediments. Journal of Geology 30: 377-392.

Wójcik A and Rączkowski W, 1994. Objaśnienia do szczegółowej mapy geologicznej Polski 1:50000, Arkusz Osielec (Explanations for Detailed Geological Map of Poland, 1:50 000, sheet Osielec). Wydawnictwa Geologiczne Warszawa: 63 pp (in Polish).

Zolitschka B, Behre KE and Schneider J, 2003. Human and climatic impact of the environment as derived from colluvial, fluvial and lacustrine archives - examples from the Bronze Age to the Migration Period, Germany. Quaternary Science Reviews 22: 81-100.

Żurek S and Pazdur A, 1999. Zapis zmian paleohydrologicznych w rozwoju torfowisk Polski (Process of peat accumulation on hydrological conditions background). In: Pazdur A, Bluszcz A, Stankowski A, and Starkel L, eds., Geochronologia górnego czwartorzędu Polski, $w$ świetle datowania radiowęglowego i luminescencyjnego, WIND, Wrocław: 215-228 (in Polish).

Żytko K, Zając R, Gucik S, Ryłko W, Oszczypko N, Garlicka I, Nemčok J, Eliáš M, Menčik E and Stránik Z, 1989. Map of the tectonic elements of the Western Outer Carpathians and their Foreland. PIG Warszawa; GUDS Bratislava; UUG Praha. 